\title{
Cyanines Bearing Quaternary Azaaromatic Moieties
}

\author{
Wanda Śliwa,* Grażyna Matusiak, and Barbara Bachowska \\ Institute of Chemistry and Environmental Protection, Jan Długosz University of Częstochowa,
} Armii Krajowej Ave 13/15, 42-201 Częstochowa, Poland

RECEIVED DECEMBER 8, 2004; REVISED NOVEMBER 2, 2005; ACCEPTED MARCH 16, 2006

\begin{abstract}
Keywords Selected cyanines bearing quaternary azaaromatic moieties are presented, showing their monocyanine mers, dimers and polymers, as well as their possible applications. Cyanines having NLO propdye erties are also briefly described.

fluorescence
\end{abstract}

rectifier

\section{INTRODUCTION}

In continuation of our study concerning quaternary azaaromatics, ${ }^{1-8}$ we here present selected examples of cyanines bearing quaternary azaaromatic moieties. Quaternary azaaromatics are components of supramolecular systems promising for the design of molecular switches and machines, a theme being intensively studied now; ${ }^{9-14}$ they may be used as synthons in a number of reactions ${ }^{15-17}$ and they show biological activities. ${ }^{18-21}$ Viologens $^{22-25}$ and porphyrins ${ }^{26-28}$ bearing quaternary azaaromatic units deserve special attention. Use of quaternary azaaromatics as NAD models should be mentioned as well. $.^{29,30} \mathrm{Mo}-$ nomeric cyanines are described in the first part, followed by cyanine dimers and polymers. Application possibilities of these species are then presented, and the last part deals with cyanines showing NLO properties. The review deals with cyanines quaternized at nitrogen atom of a six-membered ring. References of papers that appeared during the period 2002- 2004 are cited.

\section{Monomeric Cyanines}

Photophysical properties of cyanine $\mathbf{1}$ and its photochemistry were investigated in 20 solvents of different polarity. The dipole moments of fluorescence emission and the twisted intramolecular CT state were estimated. ${ }^{31}$

Electronic spectra of $\mathbf{2}$ were measured in solvents of different polarity. Cyanine $\mathbf{2}$ shows inverse (negative) solvatochromism, i.e., a blue shift with an increase in solvent polarity. It was also observed that the fluorescence quantum yield is sensitive to polarity and viscosity of the medium. Investigation of the influence of micellization on the fluorescence spectrum of $\mathbf{2}$ in sodium dodecyl sulfate (SDS) showed enhancement of the fluorescence intensity with an increase of the SDS concentration ${ }^{32}$ (Scheme 1).
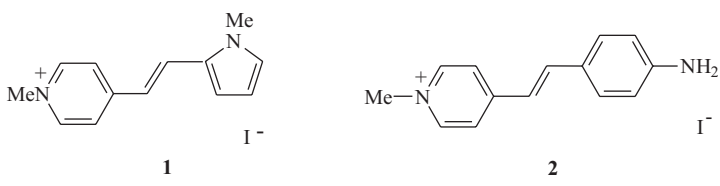

Scheme 1

* Author to whom correspondence should be addressed. (E-mail: w.sliwa@ajd.czest.pl) 
Molecular rectifiers are a topic of intensive research. $^{33-36}$ Theoretical models of molecular rectification have the structure of donor-(electron bridge)-acceptor dyes, in which chromophores are localized asymmetrically between the electrodes. Examples of molecular rectifiers are D- $\pi$-A dyes ${ }^{37,38}$ and D- $\pi$-A- $\pi$-D dyes ${ }^{39}$ aligned by the Langmuir-Blodgett (LB) technique ${ }^{33,39}$ or molecular self-assembly. ${ }^{33,40,41}$ The direction of electron flow at forward-bias is from the contact to substrate and involves electron tunneling to LUMO of the acceptor on one side of the device and from HOMO of the donor on the other side.

The rectifying dye 3a, self-assembled on gold-coated substrates was obtained. Self-assembled monolayers (SAMs) of 3a show asymmetric current- voltage characteristics. ${ }^{42}$ Protonation of the $\mathrm{C}(\mathrm{CN})_{2}$ group disrupts the donor-acceptor structure; rectification is switched off by exposure to acid, and switched on by exposure to base. It was observed that different linking groups $\left(\mathrm{Au}-\mathrm{S}_{-} \mathrm{C}_{3} \mathrm{H}_{6}\right.$ and $\mathrm{Au}-\mathrm{S}-\mathrm{C}_{10} \mathrm{H}_{20}$ ) have no influence on electrical asymmetry; rectification results from the donor-( $\pi$-bridge $)$-acceptor moiety, which is sterically hindered and non-planar.

In SAMs of $\mathbf{3 b}$, without a methyl group, the $\mathrm{D}-\pi-\mathrm{A}$ moiety is not sterically hindered; hence rectification is suppressed. ${ }^{42}$ It is suggested that the molecule adopts a quinoid form rather than a charge-separated zwitterionic form; in this way, the repulsion energy of a parallel si- de-by-side arrangement of aligned dipoles may be minimized (Scheme 2).

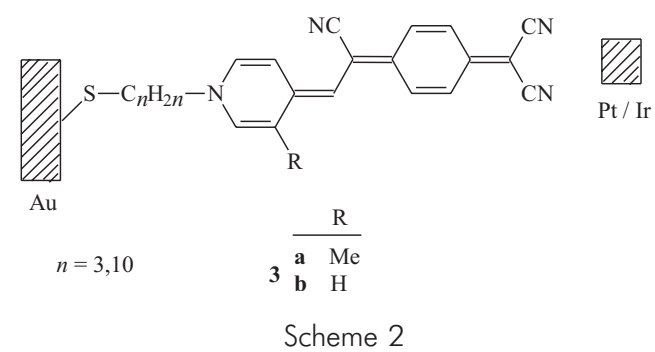

SAMs of dyes 4-10 were studied. ${ }^{40}$ Chemisorbed monolayers of dye $\mathbf{4}$ are stable in air, but the donor readily undergoes protonation $-\mathrm{NMe}_{2} \rightarrow \mathrm{N}^{+} \mathrm{HMe}_{2}$ in acidic media, resulting in disruption of the intramolecular CT axis. This process is reversible. Consequently, rectification may be chemically switched on when SAMs are briefly exposed to $\mathrm{HCl}$ vapor; subsequent exposition to $\mathrm{NH}_{3}$ restores the asymmetry.

In $\mathbf{5}$ and $\mathbf{6}$, iodide counterions are probably located between chromophores. The dipole reversal occurs when the counterion is shifted along the length of the D- $\pi-A$ chromophore; the molecular structure changes from aromatic to quinoid as the anion is located above the amino group. SAMs with sterically hindered D- $\pi$-A molecules, in which D and A are twisted out of plane, such as $\mathbf{4}$ and
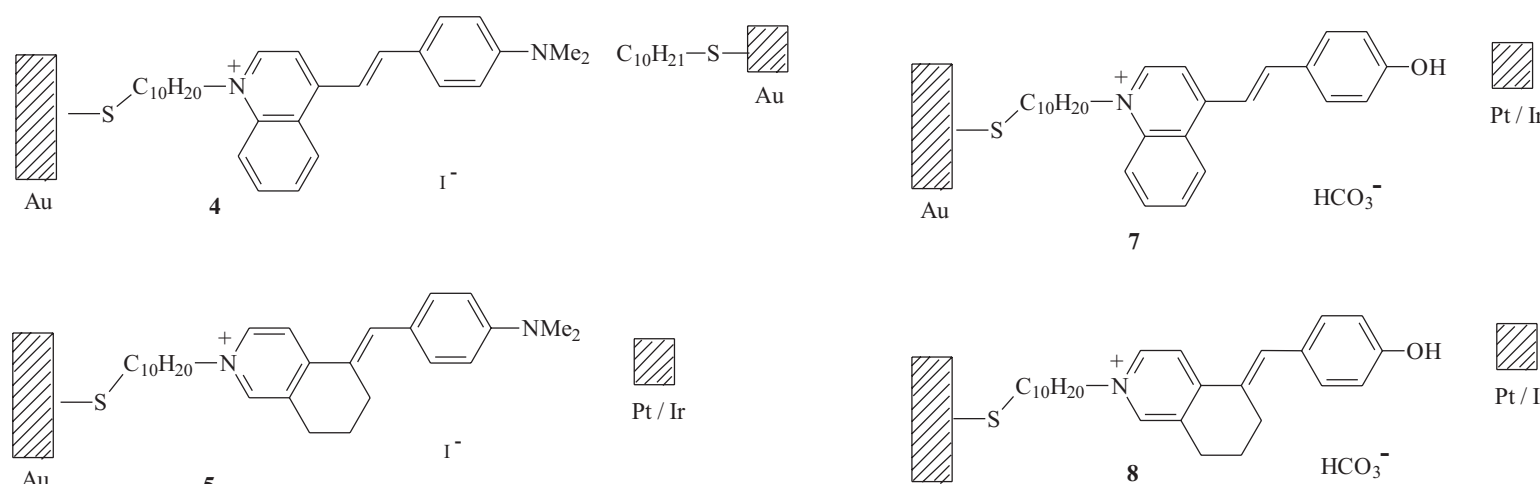

$\mathrm{Au} \quad 5$

$\mathrm{Pt} / \mathrm{Ir}$
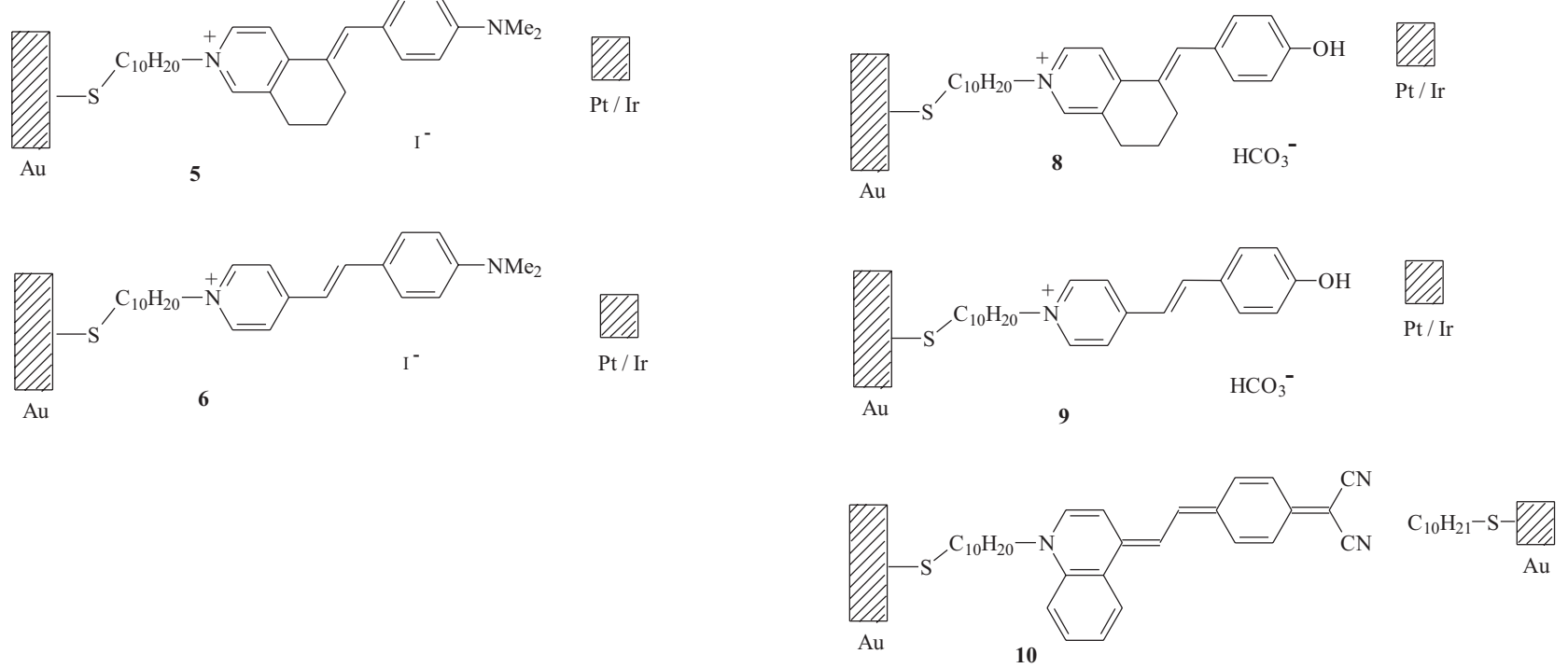
5, show rectification while in the case of planar molecules, such as $\mathbf{6}$, no rectification occurs.

Dyes 7-9 are protonated merocyanines. They self-assemble in the presence of $\mathrm{NH}_{4} \mathrm{OH}$ to give colored merocyanine forms. These merocyanine forms are unstable, they readily protonate $\left(\mathrm{C}_{6} \mathrm{H}_{4} \mathrm{O}^{-} \rightarrow \mathrm{C}_{6} \mathrm{H}_{4} \mathrm{OH}\right)$, presumably with atmospheric $\mathrm{H}_{2} \mathrm{CO}_{3}$. Protonation disrupts the $\mathrm{CT}$ axis; as a consequence, a loss of color occurs and the second harmonic generation is suppressed, but both may be restored upon exposure to $\mathrm{NH}_{3}$ vapor.

Dye $\mathbf{1 0}$ is an analogue of the air-sensitive merocyanine 7 , in which the oxygen atom is substituted by the $\mathrm{C}(\mathrm{CN})_{2}$ group, and therefore its films are less susceptible to atmospheric protonation. Rectification is restored by exposure to $\mathrm{NH}_{3}$ vapor (Scheme 3). ${ }^{40}$

A spectroscopic study of $\mathbf{1 1}$ was reported. ${ }^{43}$ It was found that $\mathbf{1 1}$ shows a strong inverse solvatochromism, and its LB films behave as electrical rectifiers. ${ }^{44}$ Absorption and Raman spectra were collected from solution and solid samples, and from the LB monolayer and multilayers. Raman spectra confirm the zwitterionic character of the molecule of $\mathbf{1 1}$ in all phases, whereas absorption spectra are dependent on the molecular environment. The inverse solvatochromism of $\mathbf{1 1}$ was analyzed using the Mulliken-Holstein model, usually serving to describe spectral properties of normal solvatochromic dyes (Scheme 4). ${ }^{45}$

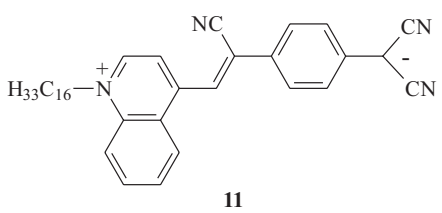

Scheme 4

Dye 12 is a molecular rectifier, its LB films show asymmetric current-voltage characteristics. However, it should be noted that its analogue $\mathbf{1 3}$ behaves differently. In 12, i.e., in the aromatic form, the counterion is adjacent to heterocyclic moiety, whereas in $\mathbf{1 3}$, i.e., in the quinoid form, the counterion is relocated towards the dibutylamino group. ${ }^{38}$ Theoretical calculations confirm that such a counterion relocation results in dipole reversal and in transition from the aromatic to the quinoid form. The monolayer structure of $\mathbf{1 3}$ is non-centrosymmetric (Scheme 5).

Density functional vertical self-consistent reaction field (VSCRF) theory was applied for solvatochromic studies of solvent-sensitive dyes; as an example, the Brooker merocyanine $\mathbf{1 4}$ was investigated. ${ }^{46,47}$ The predicted blue shifts of the vertical excitation energies in different solvents occurring with increasing polarity from heptane to water solutions are in very good agreement with experiment.

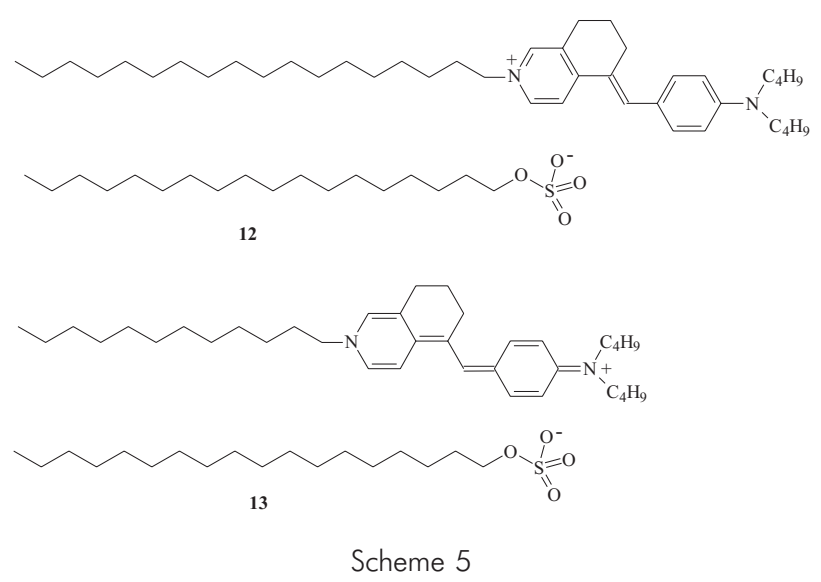

The $E_{\mathrm{T}}$ polarity values of $\mathbf{1 4}$ were recorded in binary solvent systems consisting of formamides ( $N, N$-dimethylformamide, DMF, methylformamide, NMF, and formamide, FA) and hydroxylic solvents (water, methanol, ethanol, propan-2-ol, butan-2-ol). Mixtures of DMF with NMF and FA were also investigated. ${ }^{48}$ It was found that the preferential solvation is determined by solute-solvent and solvent-solvent interactions. The synergism observed in many binary systems, e.g., DMF/propan-2-ol, DMF/butan-2-ol, FA/methanol, FA/ethanol results from solvent-solvent interactions (Scheme 6).

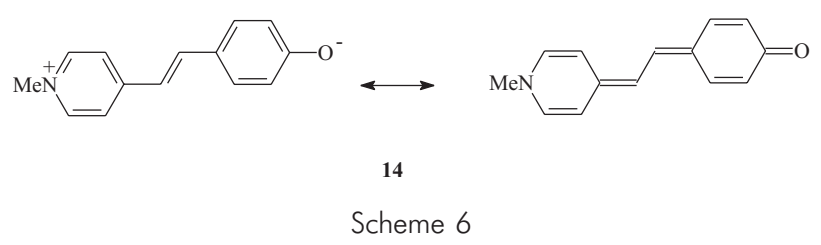

The above mentioned works point to the importance of chemistry and behavior of theoretical models for molecular rectification. ${ }^{42,43}$

Attention should be also paid to solvatochromic studies of solvent-sensitive monomeric cyanines. Dyes with strong solvatochromic properties are used as probes in investigations of micelle/solution interfaces and model liquid membranes; they also serve for solvent polarity determination. ${ }^{48}$ The solvatochromic effects are useful in sensing protein activity in living cells. ${ }^{46}$

\section{Dimeric and Polymeric Cyanines}

Due to the zwitterionic character of $\mathbf{1 5}$, its dipole moment is high, resulting in the formation of dimer $\mathbf{1 6}$ by dipolar aggregation; there is equilibrium between two monomeric molecules of $\mathbf{1 5}$ and one dimer molecule of $\mathbf{1 6 .}$

The strong effect of an external electric field on the dipolar aggregation of $\mathbf{1 5}$ was investigated by electrooptical absorption measurements. ${ }^{49-51}$ It was confirmed experimentally that the external field stabilizes the highly 


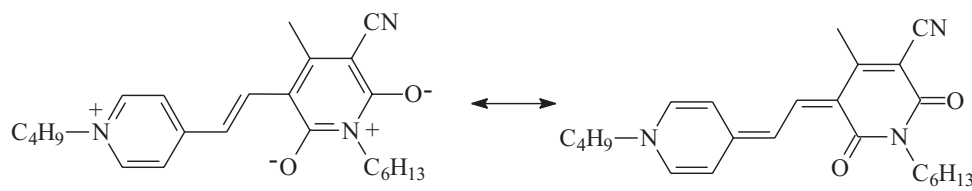

15

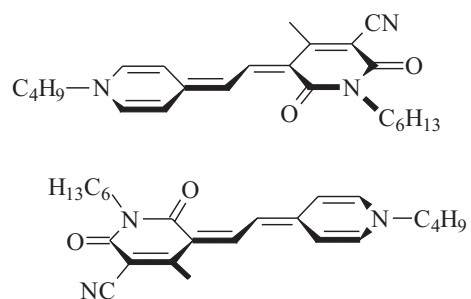

16

Scheme 7

dipolar monomeric form compared to the weakly dipolar dimeric form (Scheme 7).

Resonance Raman intensity analysis was conducted for $\mathbf{1 7}$ and $\mathbf{1 8}$ as monomers in dichloromethane solutions and as H-dimers in dioxane solutions. ${ }^{51-53}$ Dyes $\mathbf{1 9}$ have large dipole moments in the ground and excited states, showing considerable contributions of structures $\mathbf{A}$ and C. ${ }^{51}$

It was concluded that the resonance Raman excitation profiles and the basic features of the optical absorption spectra of H-dimers may be well explained by a simple molecular exciton model, which assumes that the two monomers interact through coupling between their transition dipole moments; the excitonically coupled monomer model is not adequate here (Scheme 8).

Dyes 1, 20 and 21 were synthesized. ${ }^{54}$ Self-aggregation of $\mathbf{1}$ and $\mathbf{2 1}$ gave nanorods and nanospheres, respectively, by changing the solvent during the synthesis. For example, the aggregation of $\mathbf{1}$ resulted from injecting the ethanolic solution of $\mathbf{1}$ into a 1:1 mixture of hexane and methyl cyclohexane. The above nanostructures have well-defined shapes and uniform sizes. The main driving force for the formation of nanostructures are the strong interactions between molecules. Dye $\mathbf{2 0}$ aggregates into rodlike nanostructures; however, their morphology is undefined (Scheme 9).
In the study of dye organization, promising for the design of functional organic materials for electronics and photonics, ${ }^{55,56}$ highly ordered merocyanine dye assemblies were obtained by supramolecular polymerization and hierarchical self-organization. ${ }^{57}$

Supramolecular properties of dyes $\mathbf{2 2}$ and $\mathbf{2 3}$ result from their very large dipole moments; they have highly polarizable $\pi$-systems, responsible for their functionalities. Dyes $\mathbf{2 2}$ and $\mathbf{2 3}$ bear tridodecyloxyl substituents, enabling their solubility in nonpolar solvents; this allows the highest binding strength of electrostatic interactions. ${ }^{51}$

UV/Vis spectroscopy results show an equilibrium between monomers and two different types of aggregates, characterized by blue-shifted D- and H-type absorption bands. D-band indicates the formation of oligomeric/polymeric supramolecular chain, and the H-band shows the presence of a higher-order assembly. ${ }^{58}$

It was established that dye $\mathbf{2 2}$ undergoes dimerization, while $\mathbf{2 3}$ undergoes supramolecular polymerization due to dipolar aggregation. Polymerization of $\mathbf{2 3}$ in nonpolar solvents affords viscous and viscoelastic polymers. The resulting structure is a random-coil polymeric chain, which folds to give a helical conformation. Intertwining of six polymeric chains forms a tightly packed rod containing each dye with tridodecyloxyl groups pointing to the outside, in this way providing solubility in nonpolar
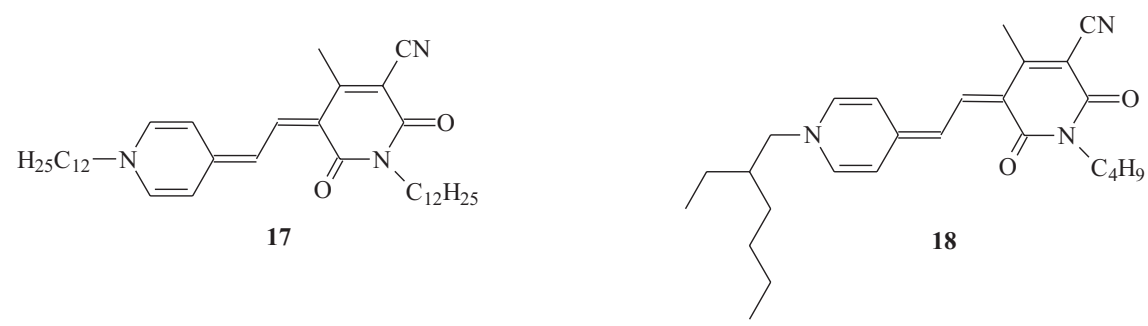

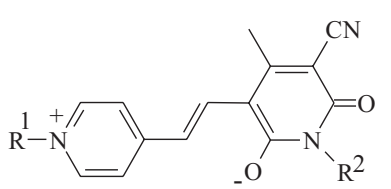

A

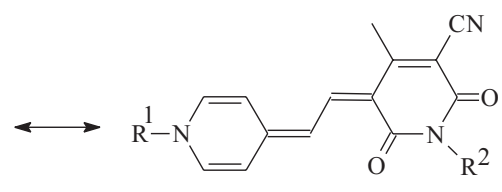

B

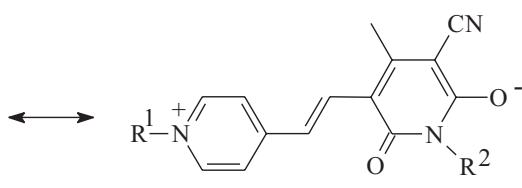

C

19

Scheme 8 

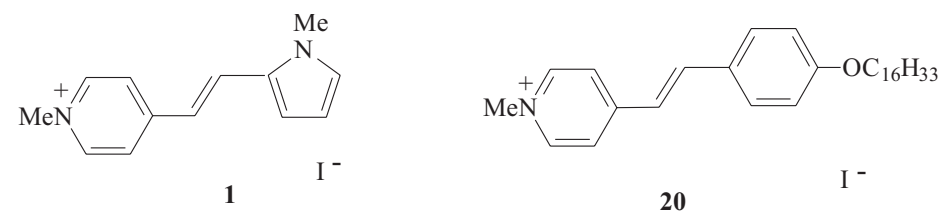<smiles>CCCCOc1ccc(/C=C/c2cccc(/C=C/c3ccc(OCCC)cc3)[n+]2C)cc1</smiles>

21

$\mathrm{I}^{-}$

Scheme 9

environments. This structure resembles that of natural chlorophyll rod elements in chromosomes of photosynthetic bacteria. ${ }^{59} \mathrm{Gel}$ formation is observed at higher concentrations. The solvent evaporation affords films showing hexagonal columnar ordering (Scheme 10)..$^{58}$
Reversible light-driven morphological changes in multilamellar films of $\mathbf{2 4}$ cast on glass plates have been observed. ${ }^{60}$ Controlled structural changes in the alignment begin with the photocyclodimerization of the stilbazolium moieties of aryl carboxylate salts. The $s y n-\mathrm{HH}$<smiles>CCCCCCCCCCOc1ccc(CN2C=CC(=CC=C3C(=O)N(CC)C(=O)C(C#N)=C3C)C=C2)c(OCC)c1OC</smiles>

22

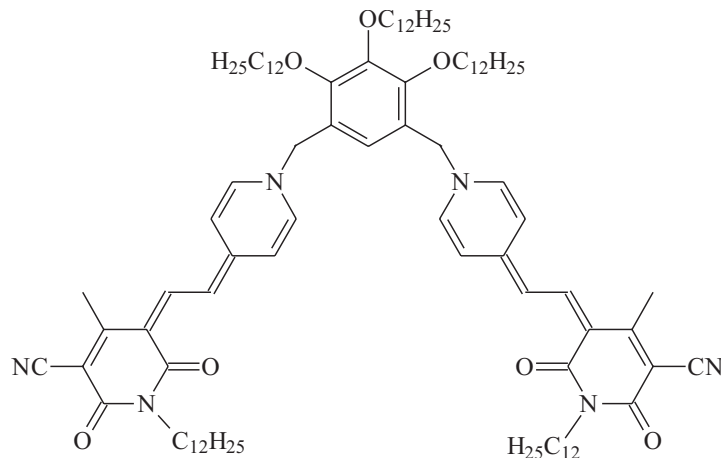

23
2

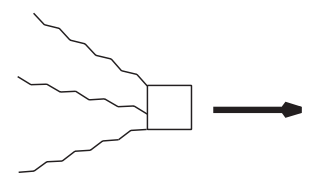

22

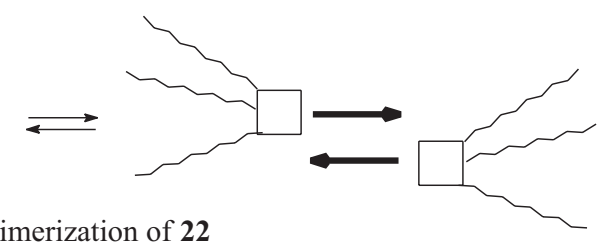

dimerization of $\mathbf{2 2}$

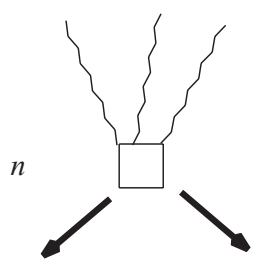

23

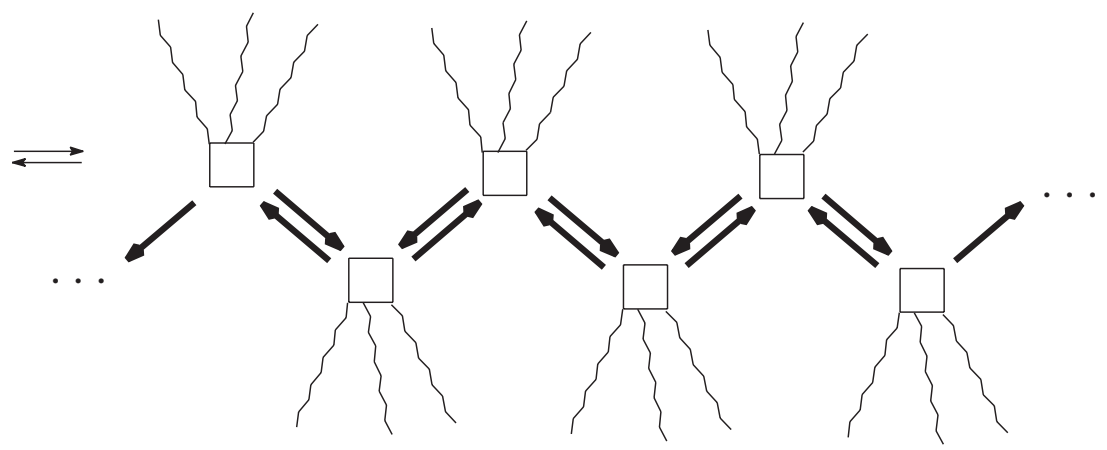

polymerization of $\mathbf{2 3}$

Scheme 10 


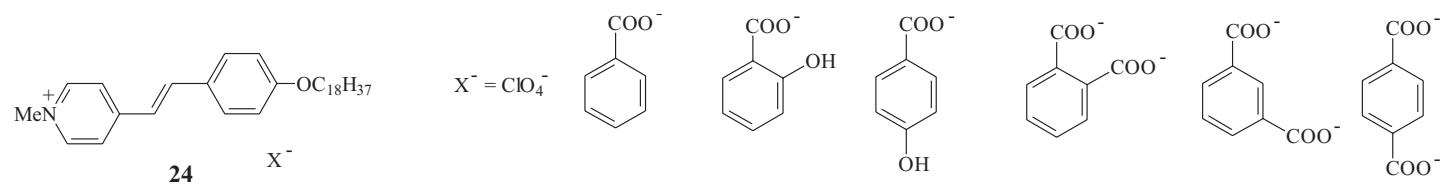<smiles>COc1ccc(CCc2ccc(O)cc2)cc1</smiles><smiles></smiles>

Scheme 11

dimers and anti-HH dimers are formed when counterions $\mathrm{X}^{-}$are 1,2-, 1,3- and 1,4-benzenedicarboxylates. The alignment of $\mathbf{2 4}$ self-assembly in cast films may be controlled by some salt counterions, the property being promising for the design of photofunctional recording materials (Scheme 11).

Dyes $(E)$-25a-e, promising as photoswitchable ionophores have been synthesized. ${ }^{61}$ In the presence of $\mathrm{Mg}\left(\mathrm{ClO}_{4}\right)_{2}$ in MeCN, $(E)$-25a-e show a large blue shift of their long-wavelength absorption bands, resulting from charge redistribution within the dye molecule, induced by $\mathrm{Mg}^{2+}$ coordination to the crown ether unit (shown for $(E)$-25e) (Scheme 12).
Irradiation of $[(E)-\mathbf{2 5 e}] \cdot \mathrm{Mg}^{2+}$ in $\mathrm{MeCN}$ with visible light leads to the anion capped complex $[(Z)-25 \mathbf{e}] \cdot \mathrm{Mg}^{2+}$, which upon addition of water undergoes dissociation affording (Z)-25e and releasing $\mathrm{Mg}^{2+}$, which is strongly solvated by water (Scheme 13).

The $E$ isomers of 25a-d form also 2:2 complexes with $\mathrm{Mg}^{2+}$ in acetonitrile, in which two dye molecules are arranged syn-head-to-tail. The ${ }^{1} \mathrm{H}$ NMR spectroscopy results have shown that complexes $[(E)-\mathbf{2 5} \mathbf{a}-\mathbf{d}] \cdot \mathrm{Mg}^{2+}$ undergo stereospecific photocyclodimerization, yielding in each case single cyclobutane stereoisomers 26a-d. Z-isomers of 25a-e form anion-capped 1:1 complexes with $\mathrm{Mg}^{2+}$; therefore, they do not undergo photocyclodimerization (Scheme 14). ${ }^{61}$
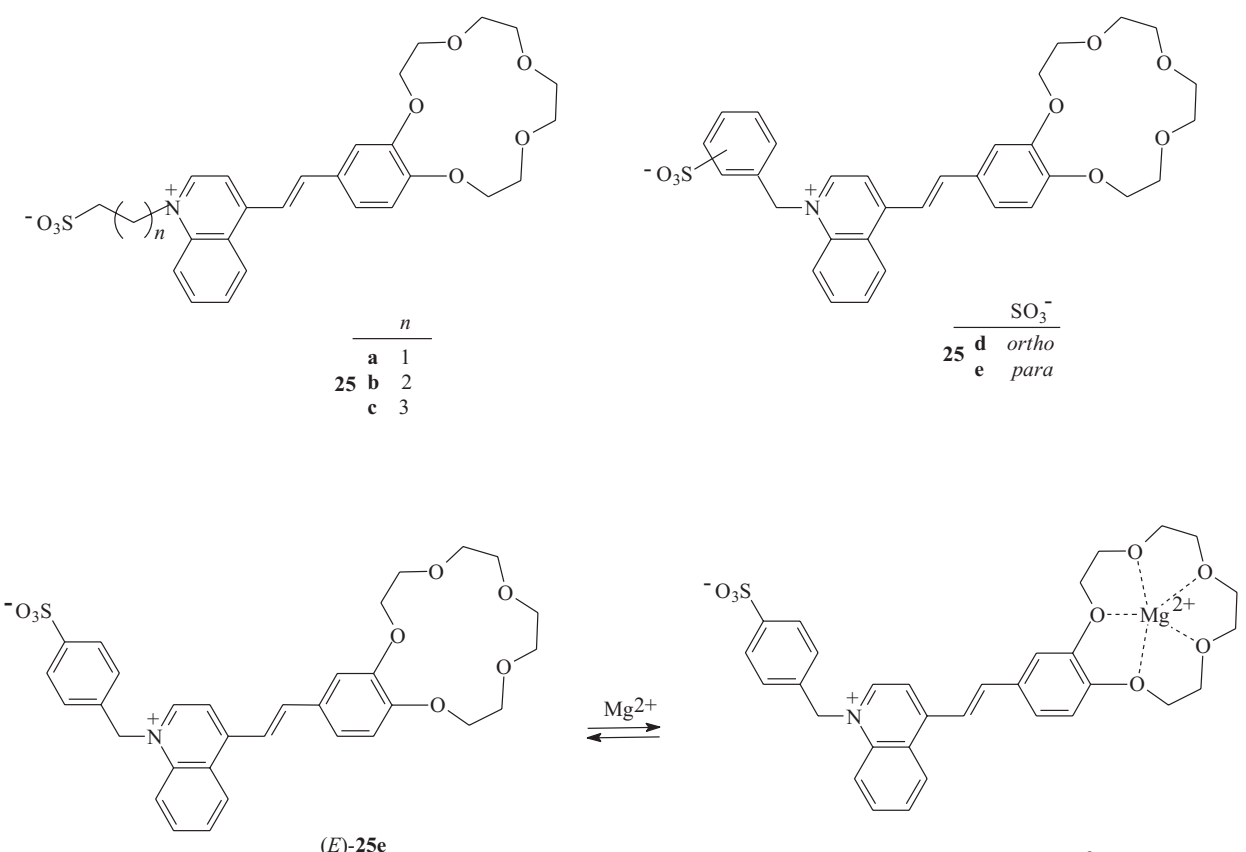

$[(E)-\mathbf{2 5 e}] \cdot \mathrm{Mg}^{2+}$

Scheme 12 


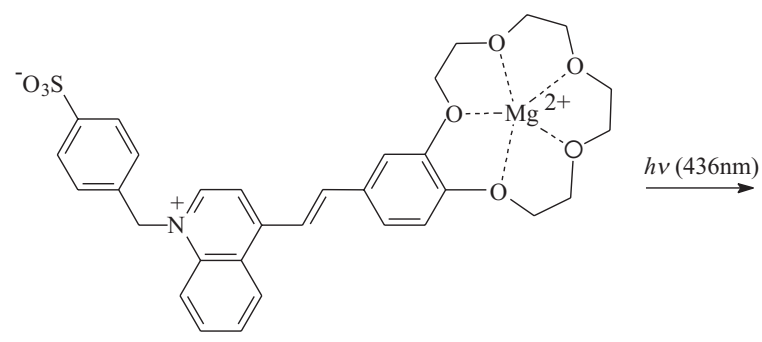

$[(E)-\mathbf{2 5 e}] \cdot \mathrm{Mg} 2+$

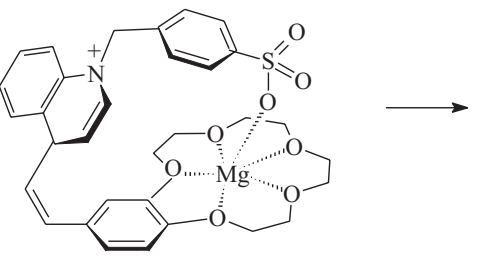

$[(Z)-25 e] \cdot M g 2+$

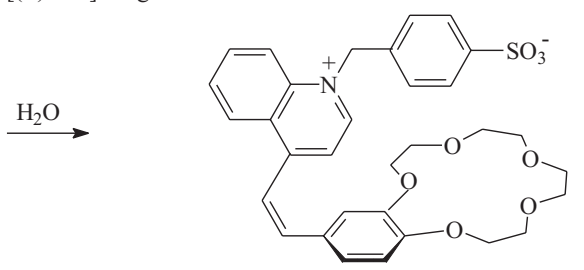

(Z)-25e

Scheme 13

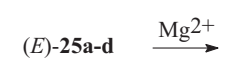

- benzocrown
- benzocrown $\cdot \mathrm{Mg}$

- heterocycle

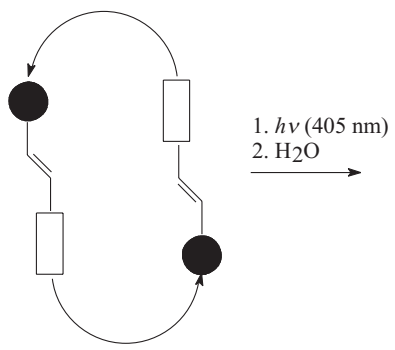

syn $-\left\{[(E)-\mathbf{2 5 a}-\mathbf{d}] \cdot \mathrm{Mg}^{2+}\right\}_{2}$

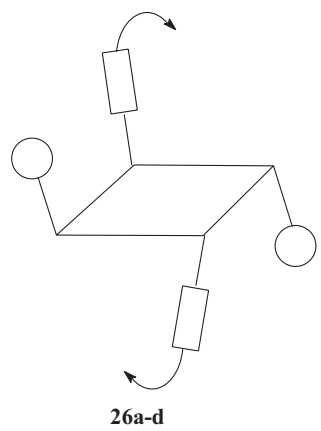

photocyclodimerization of (E)-25a-d

$\bigcirc=\left(\mathrm{CH}_{2}\right)_{n} \mathrm{SO}_{3}{ }^{-}$or $\mathrm{CH}_{2}-\mathrm{o}-\mathrm{C}_{6} \mathrm{H}_{4}-\mathrm{SO}_{3}{ }^{-}$

Scheme 14

The above section points to the easy preparation of organic low-dimensional aggregates with well defined shapes and uniform sizes from dyes $\mathbf{1}$ and $\mathbf{2 1 .}{ }^{54}$ Such nanostructures show electrical and optical properties depending on their shape and size, which may be modified; they are used as building blocks in the construction of nanodevices.

\section{Possibilities of Cyanines Application}

It was observed that polymer composites containing cyanine dye $\mathbf{2 7}$ show asymmetric two-beam coupling through pseudorefraction, i.e., without a space-charge field and orientational effects. ${ }^{62}$ In such polymer composites based on pseudophotorefraction, no electric field is necessary for poling or assisting photoconduction; hence no use of two transparent electrodes is required, a fact reducing optical losses and having a great advantage over conventional photorefractive polymers (Scheme 15).
The cell permeable DNA sensitive dye $\mathbf{2 8}$ was developed by extended combinatorial synthesis and cell-based localization screening. ${ }^{63}$ It was observed that 28 shows increased fluorescence intensity upon addition of DNA.

Compounds $\mathbf{2 9}$ and $\mathbf{3 0}$, which are trans isomers, have been synthesized. ${ }^{64}$ Exposure of $\mathbf{2 9}$ and $\mathbf{3 0}$ to visible light leads to mixtures of cis and trans isomers, which were separated by HPLC. The trans isomers are planar and thermodynamically more stable than cis isomers, in which the pyridinium and naphthalene moieties are not

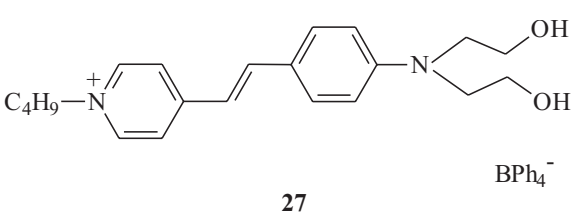

Scheme 15 


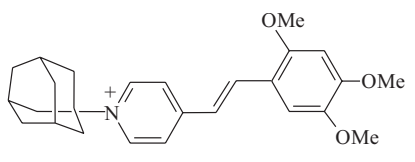

28

$\mathrm{Br}^{-}$

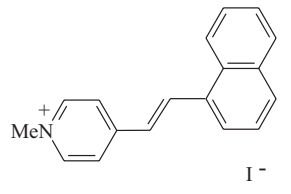

29

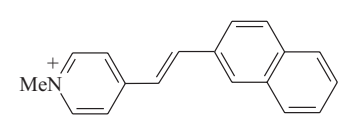

$30 \quad I^{-}$
Scheme 16

coplanar with the ethylene bond. Interactions of cis and trans isomers with DNA were investigated by UV-Vis absorption and circular dichroism measurements. The trans isomers interact with DNA by intercalation, their binding being stronger than that of cis isomers (Scheme 16). ${ }^{64}$

A method for enzyme-induced selective staining of membranes and cells by fluorescent voltage-sensitive dyes has been reported. ${ }^{65-67}$ It involves an increase in the binding strength of the dye to membranes by enzymatic cleavage of a functional group that impairs binding. This method may be used for selective labeling of brain nerve cells in studies of signal processing. Cell-selective staining involves extracellular application of an organic precursor dye and its local activation at a selected cell by a genetically encoded enzyme.

In the study of dyes 31-33, the sulfonato head group of $\mathbf{3 1}$ was replaced by a phosphate to give 32, which upon hydrolysis afforded alcohol 33. Phosphate was chosen because it has a high polarity resulting from two negative charges in moderately alkaline solution and because activation relies on alkaline phosphatase, which is an enzyme with a broad range of substrate specificity. The partition coefficient of the dyes between water and membrane in a suspension of liposomes was character-

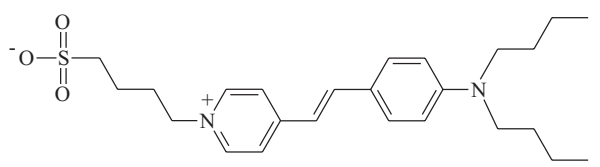

31

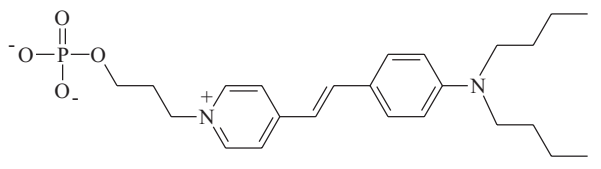

32

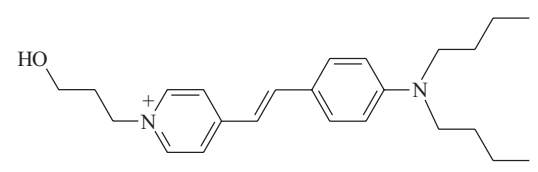

33

Scheme 17 ized. It was shown by fluorescence titration with lipid vesicles that the phosphate group lowers the partition coefficient from water to membrane.

The above staining method was tested by fluorescence microscopy with individual giant lipid vesicles and with individual red blood cells. In both systems, the membrane fluorescence due to the bound hemicyanine was enhanced. The cleavage of the phosphate appendix by alkaline phosphatase from the human placenta was investigated by liquid chromatography and isothermal titration calorimetry (Scheme 17). ${ }^{65}$

Dipyridinium ethylene 34 forms with bis(18-crown6)stilbene $\mathbf{3 5}$ the CT complexes $\mathbf{3 4 \cdot 3 5}$ and $\mathbf{3 5} \cdot \mathbf{3 4} \cdot \mathbf{3 5}$; they have been studied by surface-enhanced Raman scattering spectroscopy (SERS) ${ }^{68}$ Investigation of CT complexes is promising for their use in the design of molecular devices (Scheme 18). ${ }^{68}$

In the search for two-photon pumped laser dyes, the inner salts 36a-e have been synthesized and their linear absorption, two-photon absorption and emission properties have been studied. ${ }^{69}$ For comparison, 37a,b and 38a,b have been used. All dyes show high effective two photon absorption (TPA) cross-section values $\sigma^{(2)}$ at a wavelength of $1064 \mathrm{~nm} .{ }^{69}$ The inner salts $\mathbf{3 6}$, especially 36e, show enhanced two-photon pumped lasing as compared to $\mathbf{3 7}$ and $\mathbf{3 8}$.

Inner salts 36a-e have two mesomeric structures-A (predominant in the ground state) and $\mathbf{B}$ (predominant in the first excited state). To reach a favorable configuration, inner salt molecules interact with the neighboring molecules, affording dimers and chain-like oligomers (Scheme 19).

Two-photon absorption (TPA) of $\mathbf{3 9}$ and $\mathbf{4 0}$ has been studied. ${ }^{70}$ It was found that the TPA cross-section values decrease in the order 40b $>40 \mathrm{a}>39$. The $\sigma^{(2)}$ for $40 \mathrm{~b}$ is one of the highest values obtained for molecules of a similar size using femtosecond pulses. These results suggest that the presence of the diacetylene bridge is promising for the design of high performance TPA materials.

Some cyanine dyes show a characteristic, narrow $\mathrm{J}$-band, resulting from the formation of J-aggregates. It was observed that $\mathrm{J}$-aggregates may exhibit second- and third-order nonlinearity. ${ }^{71}$ The influence of inorganic salts and bases on the kinetics of the formation of the J-band of pseudoisocyanine iodide (PIC iodide) in diluted and concentrated aqueous solutions has been investigated. ${ }^{71,72}$ Absorption spectra of diluted solutions of PIC iodide containing inorganic salts show an intense J-band, its position depending on the anion of the salt. However, absorption spectra of concentrated solutions of PIC iodide containing inorganic salts show two J-bands, a »red « and a »blue « one; the position of the blue band depends on the anion of the salt. ${ }^{71}$

In a study of layered titanates, ${ }^{73}$ a convenient method for fabrication of titanate-dye hybrids as a film was 

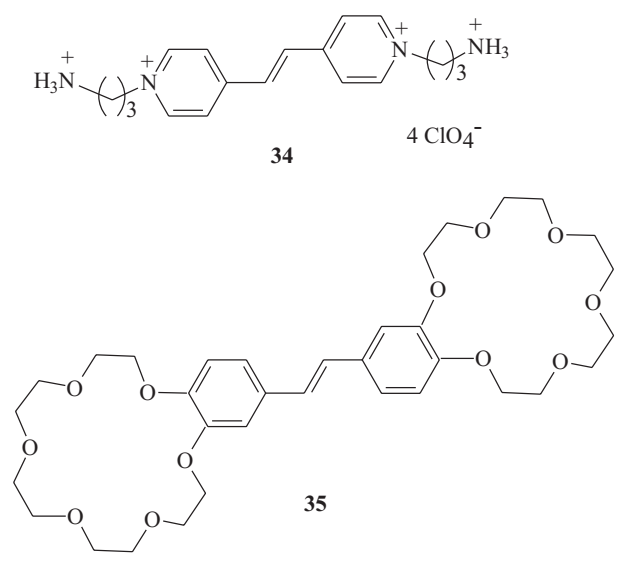

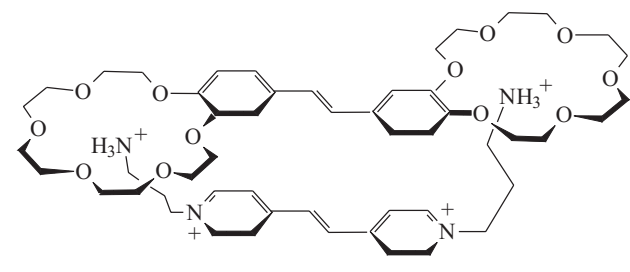

$34 \cdot 35$

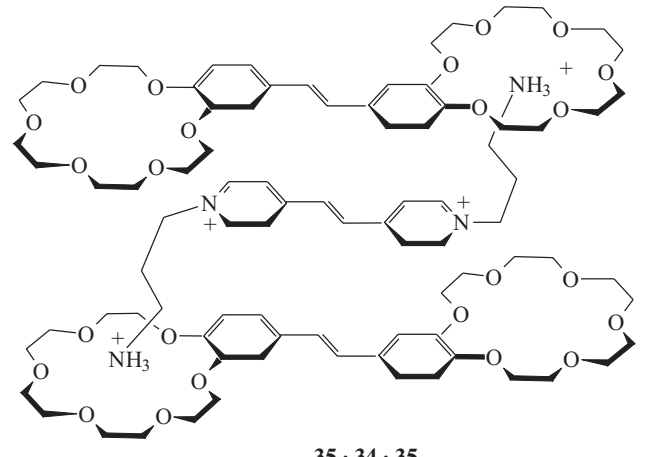

Scheme 18
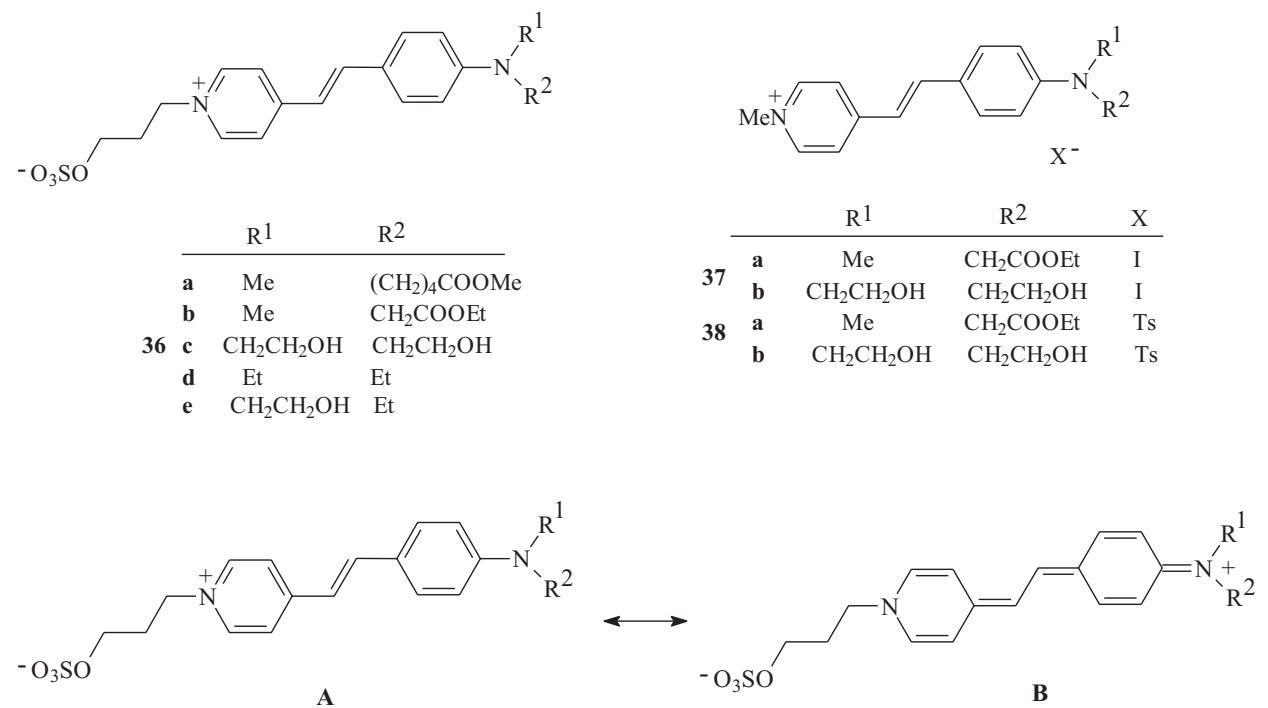

Scheme 19

reported, using PIC bromide as a dye. ${ }^{74}$ The layered titanate $\mathrm{Na}_{2} \mathrm{Ti}_{3} \mathrm{O}_{7}$ ion-exchanged with propylammonium ions was swelled and exfoliated to single layers, then thin films of the titanate were prepared by restacking the exfoliated titanate sheets.

Taking advantage of the ion-exchange capability of the film, a supramolecular composite film was fabricated by alternating intercalation of PIC bromide as J-aggregates into the pre-deposited propylammonium-exchanged $\mathrm{Na}_{2} \mathrm{Ti}_{3} \mathrm{O}_{7}$ films; the film transparency and morphology were retained in this procedure. The prepared multilayer composite of the semiconducting titanate layers and J-aggregates is interesting for construction of electronic and optical devices (Scheme 20). ${ }^{74}$
Among the reports of the above section, the DNA binding by cyanines deserves attention. ${ }^{63,64}$ Synthesis of the DNA sensitive dye 28, a fluorescence sensor that belongs to cell permeable nuclear staining dyes, is promising for the live cell imaging purposes. ${ }^{63}$

\section{Cyanines Showing NLO Properties}

NLO materials are a topic of intense research owing to their use in various fields, such as optical data storage, optical information processing and telecommunications. ${ }^{75}$ Cyanine dyes showing NLO properties are interesting, for example, for imaging of biological processes and for construction of neuroelectronic devices. ${ }^{76}$ In the search for push-pull conjugated compounds promising 


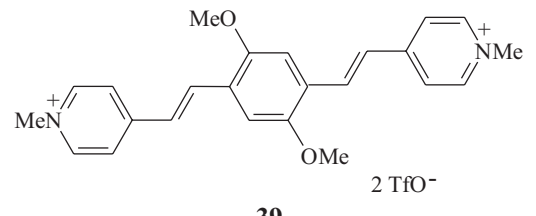

39
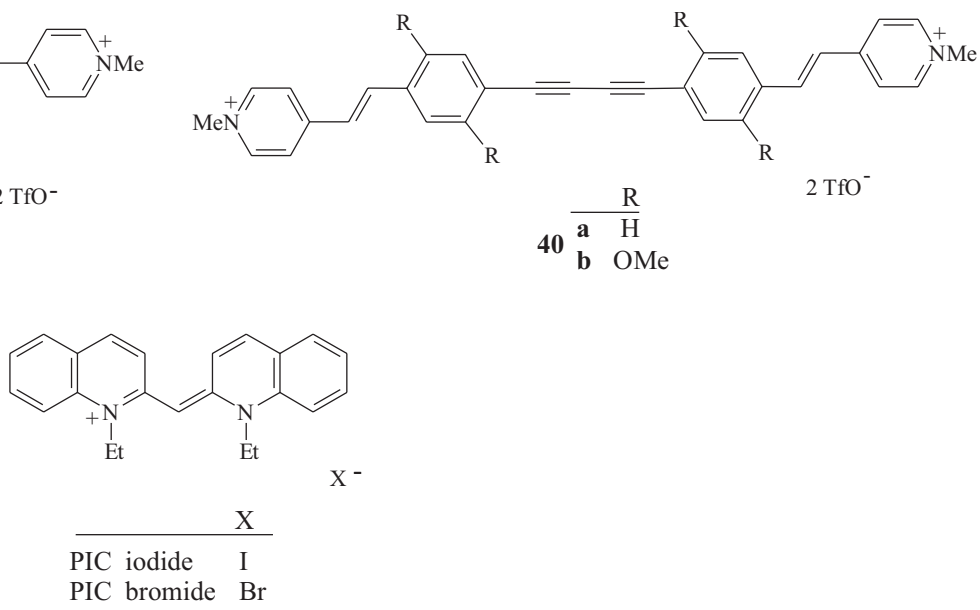

Scheme 20

in the design of NLO materials, dyes $\mathbf{4 1 - 4 3}$ were investigated. ${ }^{51,77,78}$ It was observed that the quinoid character of 41-43 increases with higher annelation, i.e., in the order $\mathbf{4 1}<\mathbf{4 2}<\mathbf{4 3}$.

The first hyperpolarizability $\beta_{\text {o }}$ of dyes $\mathbf{4 1 - 4 3}$ is strongly affected by cooperation of their structure and the environment polarity. These species are highly polarizable molecules, which are primarily zwitterionic over a large range of high dielectric constants of the solvent; the contribution of their quinoid forms grows with the decrease of the solvent dielectric constant. Dyes 41-43 give access to large second-order molecular NLO activities, provided the solvent polarity is suitable (Scheme 21). ${ }^{77}$

Organic transition metal complexes may combine redox or magnetic behavior with NLO properties, a fact interesting for construction of multifunctional materials. It was established that some ruthenium pyridyl ammines containing pyridine groups often have very high $\beta_{\mathrm{o}}$ values, associated with intense, low energy metal-to-ligand
CT (MLCT) excitations. ${ }^{79}$ In trans $\left[\mathrm{Ru}^{\mathrm{II}}\left(\mathrm{L}_{\mathrm{A}}\right) \mathrm{L}\left(\mathrm{NH}_{3}\right)_{4}\right]^{2+}$ complexes $\left(\mathrm{L}_{\mathrm{A}}=\right.$ electron acceptor pyridine ligand, $\mathrm{L}=$ electron donor, neutral or anionic ligand), the electrondonating strength of the $\mathrm{Ru}^{\mathrm{II}}$ center can be modified by changes of $\mathrm{L}_{\mathrm{A}}{ }^{79}$ and $\mathrm{L} .{ }^{80}$

Quadratic nonlinear optical properties of polyenes 44-47 have been investigated. ${ }^{79,81,82}$ It was found that the intense visible $\mathrm{d} \rightarrow \pi^{*}$ MLCT bands blue-shift when $n$ increases, and the static first hyperpolarizabilities $\beta_{\text {o }}$ maximize at $n=2$, i.e., the conjugation extension does not lead to a continual increase in $\beta_{0}$, in contrast to other D-A polymers in which $\beta_{\mathrm{o}}$ increases with $n$ (Scheme 22).

Complex salts $\operatorname{trans}\left[\mathrm{Ru}^{\mathrm{II}}\left(\mathrm{L}_{\mathrm{A}}\right)(\mathrm{NCS})\left(\mathrm{NH}_{3}\right)_{4}\right]\left[\mathrm{PF}_{6}\right]_{2}$ 48-51 having different $\mathrm{L}_{\mathrm{A}}$ ligands have been obtained and their non-linear optical properties have been measured. ${ }^{80}$ The electron absorption spectra of $\mathbf{4 8 - 5 1}$ show intense, visible MLCT bands with energies $\left(E_{\max }\right)$ decreasing in the order $51>49 a>48 a>49 b>49 c>48 b>50$ as the electron-accepting ability of $\mathrm{L}_{\mathrm{A}}$ increases.<smiles>[R][n+]1ccc(/C=C/c2ccc(C(C#N)C#N)s2)cc1</smiles><smiles>[R]N1C=CC(=CC=c2ccc(=C(C#N)C#N)s2)C=C1</smiles>

41<smiles>[R7][n+]1ccc(/C=C/c2ccc(C(C#N)C#N)s2)c2ccccc21</smiles><smiles>[R]N1C=CC(=C/C=c2\ccc(=C(C#N)C#N)s2)c2ccccc21</smiles><smiles>[R][n+]1c2ccccc2c(/C=C/c2ccc(C(C#N)C#N)s2)c2ccccc21</smiles><smiles>[R]N1c2ccccc2C(=C/C=c2\ccc(=C(C#N)C#N)s2)c2ccccc21</smiles>

Scheme 21 

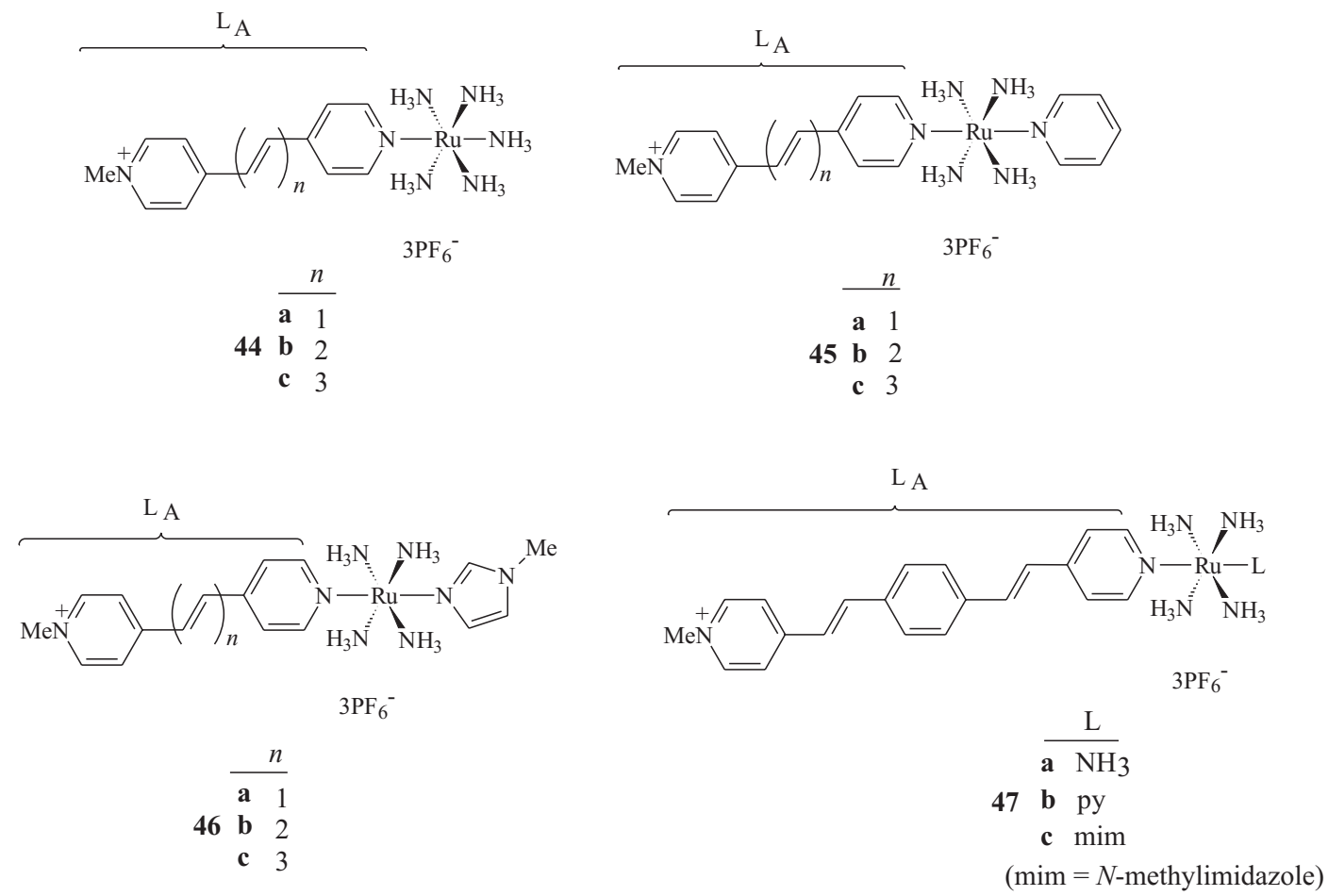

Scheme 22

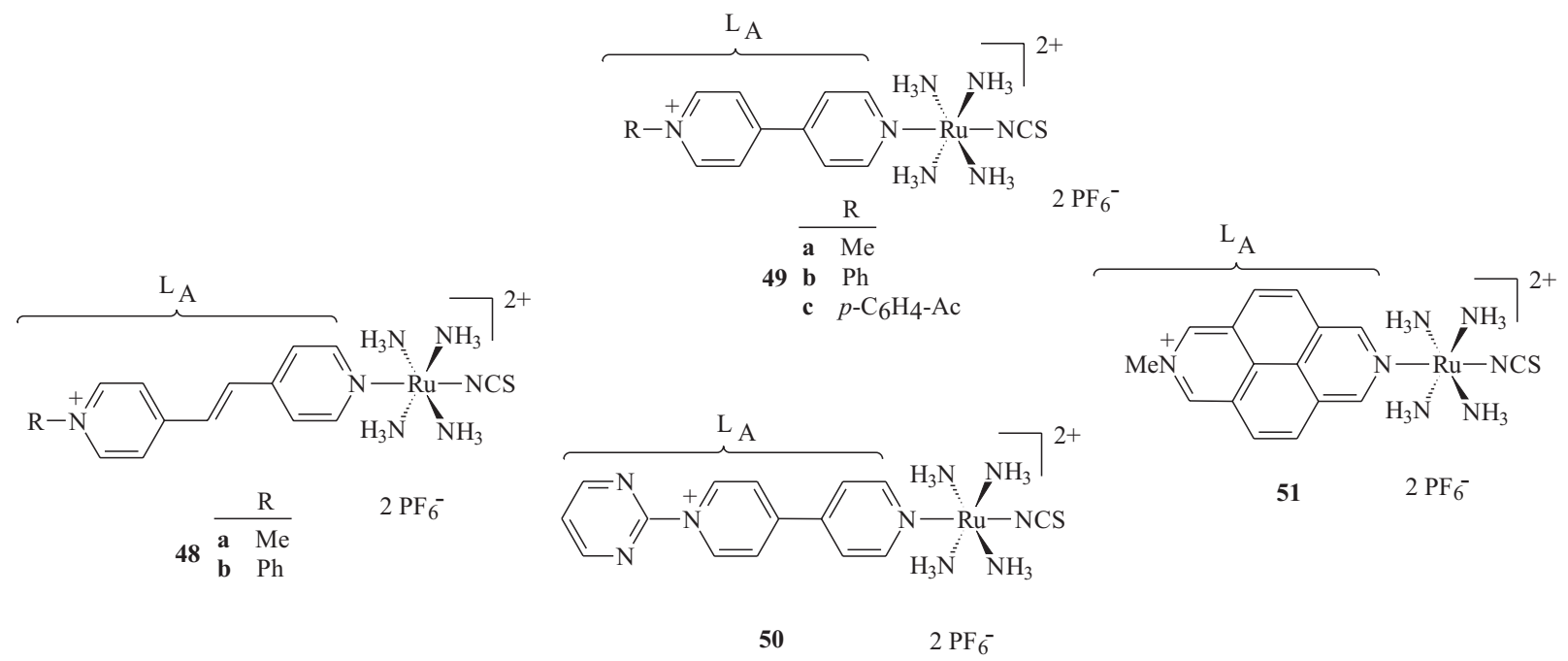

Scheme 23

It was shown by hyper-Rayleigh scattering (HRS) measurements in $\mathrm{MeCN}$ and Stark spectroscopy results that the increased electron donating ability of $\operatorname{trans}\left[\mathrm{Ru}^{\mathrm{II}}\left(\mathrm{L}_{\mathrm{A}}\right)\right.$ (NCS) $\left.\left(\mathrm{NH}_{3}\right)_{4}\right]^{2+}$ enables achievement of higher $\beta_{0}$ values compared to similar complexes containing neutral trans ligands $\mathrm{L}=\mathrm{NH}_{3}$, pyridine or $\mathrm{N}$-methylimidazole (Scheme 23). ${ }^{80}$

In the search for NLO materials, cyanines 52a-c were also obtained and their cyclic voltammetry was studied (Scheme 24). ${ }^{83} \mathrm{~A}$ method for incorporating the dipolar NLO dyes $\mathbf{5 3}$ with high $\beta_{\mathrm{o}}$ values into silica zeolite was reported ${ }^{84}$ Dyes $\mathbf{5 3}$ enter hydrophobic silicalite- 1 channels with long hydrophobic tails, resulting in their aligned inclusion into channels. The degree of uniform alignment increases with increasing $n$. These experiments show that the use of zeolite films rather than powders as the hosts for aligned inclusion of hemicyanine dyes is promising for the design of second harmonic generation materials..$^{84,85}$

The behavior of cyanines of type $\mathbf{5 4}$ in solution has been investigated. ${ }^{75}$ These compounds show inverse solvatochromism. The theoretical formulation for photoinduced charge transfer for such molecules in solution ba- 


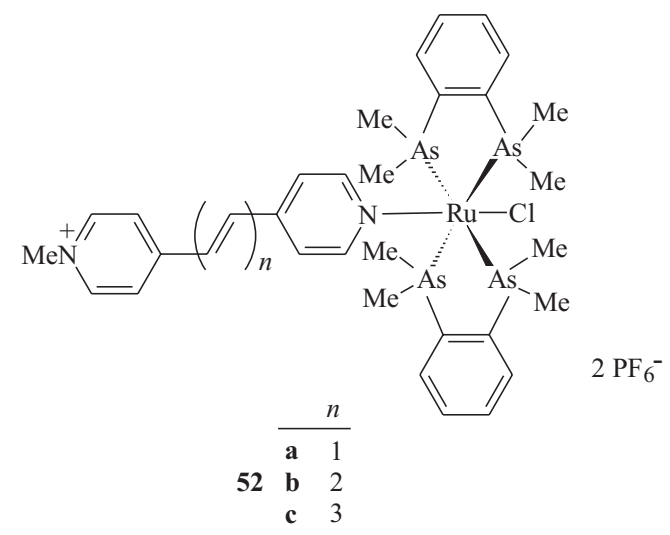

Scheme 24

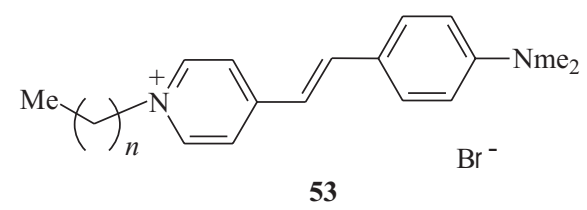

$n=2,5,8,11,14,17,21,23$

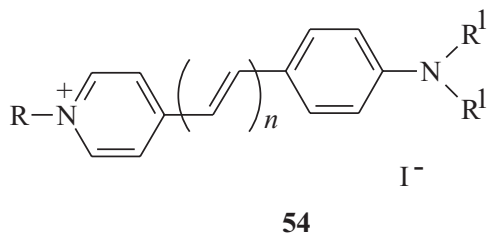

$\mathrm{R}, \mathrm{R}^{1}=$ alkyls

Scheme 25

sed on a two valence bond state electronic description has been presented. The above theory predicts when inverse solvatochromism will occur, and predicts the dependence of the NLO properties on the solution polarity, the information being useful in the design of biological systems, e.g., membranes (Scheme 25).

Among the works presented in the above section, attention should be paid to incorporation of NLO dyes $\mathbf{5 3}$ into silica zeolite. ${ }^{84}$ Zeolites and related nanoporous materials were investigated as hosts for aligned inclusion of NLO dyes in order to prepare new organic-inorganic second harmonic generation composite materials; in this way, disadvantages of organic thin films of NLO dyes may be avoided.

\section{CONCLUSION}

Chemistry of cyanines is developing rapidly, as evidenced by a large number of reports. It should be pointed out that in this field the dyes quaternized at the nitrogen atom of a six-membered ${ }^{86}$ or five-membered ${ }^{87,88}$ ring are investigated.

Interesting properties of cyanines are promising for a variety of applications, among which the optical information technologies are very important. Studies concerning nanostructures serving as building blocks in the design of nanodevices as well as sensors useful in investigations of biological processes attract special attention.

Research works dealing with the chemistry and physicochemistry of this class of compounds are numerous; the present review is not meant to be exhaustive, only selected examples are described.

\section{REFERENCES}

1. W. Śliwa, Curr. Org. Chem. 7 (2003) 995-1048.

2. J. Peszke and W. Śliwa, Spectrochim. Acta, Part A 58 (2002) 2127-2133.

3. M. Deska and W. Śliwa, Chem. Pap. 56 (2002) 309-312.

4. B. Marciniak, V. Pavlyuk, and M. Deska, Acta Crystallogr, Sect. E 58 (2002) 489-491.

5. B. Marciniak, V. Pavlyuk, and B. Dondela, Acta Crystallogr., Sect. E 58 (2002) 484-486.

6. B. Bachowska and T. Zujewska, Aust. J. Chem. 54 (2001) 105-106.

7. B. Bachowska and T. Zujewska, Monatsh. Chem. 132 (2001) 849-854.

8. B. Dondela and W. Śliwa, Chem. Heterocycl. Compd. (2000) 944-950.

9. A. P. de Silva and N. D. McClenaghan, Chem.-Eur. J. 10 (2004) 574-586.

10. P. R. Carlier, Angew. Chem., Int. Ed. 43 (2004) 2602-2605.

11. M. J. Gunter, Eur. J. Org. Chem. (2004) 1655-1673.

12. W. Śliwa and B. Bachowska, Heterocycles 63 (2004) 21312158.

13. N. Georges, S. J. Loeb, J. Tiburcio, and J. A. Wisner, Org. Biomol. Chem. 2 (2004) 2751-2756.

14. L. Jiang, J. Okano, A. Orita, and J. Otera, Angew. Chem., Int. Ed. 43 (2004) 2121-2124.

15. A. Lemire, M. Grenon, M. Pourashraf, and A. B. Charette, Org. Lett. 6 (2004) 3517-3520.

16. J. S. Yadav, B. V. S. Reddy, M. K. Gupta, A. Prabhakar, and B. Jagadeesh, Chem. Commun. (2004) 2124-2125.

17. T. Muramatsu, A. Toyota, and N. Adachi, Chem. Lett. 33 (2004) 660-661.

18. Y. Zu, Q. Li, Y. Fu, and W. Wang, Bioorg. Med. Chem. Lett. 14 (2004) 4023-4026.

19. K. Kuca, J. Cabal, J. Patocka, and J. Kassa, Lett. Org. Chem. 1 (2004) 84-86.

20. F. Hayase, T. Usui, H. Watanabe, and S. Shizukuuchi, Japan Kokai Tokkyo Koho JP 2004 250,404 (2004); Chem. Abstr. 141 (2004) 225323.

21. Y. M. Sanchez-Cantalejo, M. J. Villa Hormaeche, B. Saez Pizarro, J. Soto Romero, M. Fernandez Brana, and J.C. Lacal Sanjuan, Span. ES 2,183,734 (2003); Chem. Abstr. 140 (2004) 270844.

22. E. L. Clennan, Coord. Chem. Rev. 248 (2004) 477-492. 
23. N. Leventis, M. A. B. Meador, G. Zhang, A. Dass, and C. Sotiriou-Leventis, J. Phys. Chem. B 108 (2004) 1122811235.

24. S. Hamai, Supramol. Chem. 16 (2004) 113-120.

25. M. Álvaro, A. Corma, B. Ferrer, H. Garcia, and E. Palomares, Phys. Chem. Chem. Phys. 6 (2004) 1345-1349.

26. D. M. Guldi, I. Zilbermann, G. Anderson, A. Li, D. Balbinot, N. Jux, M. Hatzimarinaki, A. Hirsch, and M. Prato, Chem. Commun. (2004) 726-727.

27. K. Fujii, J. Nishimoto, S. Yamada, M. Fukamachi, and M. Tabata, Bull. Chem. Soc. Jpn. 77 (2004) 511-517.

28. F. S. D. S. Vilhena and S. R. W. Louro, J. Inorg. Biochem. 98 (2004) 459-468.

29. Y. Mikata, S. Aida, and S. Yano, Org. Lett. 6 (2004) 29212924.

30. B. Zhang, X.-Q. Zhu, J.-Y. Lu, J. He, P G. Wang, and J.-P. Cheng, J. Org. Chem. 68 (2003) 3295-3298.

31. C.-L. Zhan and D.Y. Wang, J. Photochem. Photobiol., A 147 (2002) 93-101.

32. S. A. El-Daly, M. H. Abdel-Kader, R. M. Issa, and E.-S. A. El-Sherbini, Spectrochim. Acta, Part A 59 (2003) 405-411.

33. G. J. Ashwell, A. Chwialkowska, and L. R. H. High, J. Mater. Chem. 14 (2004) 2389-2394.

34. K. Stokbro, J. Taylor, and M. Brandbyge, J. Am. Chem. Soc. 125 (2003) 3674-3675.

35. G. J. Ashwell, R. Hamilton, and L. R. H. High, J. Mater. Chem. 13 (2003) 1501-1503.

36. A. Troisi and M. Ratner, J. Am. Chem. Soc. 124 (2002) 14528-14529.

37. G. J. Ashwell, D. S. Gandolfo, and R. Hamilton, J. Mater. Chem. 12 (2002) 416-420.

38. G. J. Ashwell and D. S. Gandolfo, J. Mater. Chem. 12 (2002) $411-415$

39. J. W. Baldwin, R. R. Amaresh, I. R. Peterson, W. J. Shumate, M. P. Cava, M. A. Amiri, R. Hamilton, G. J. Ashwell, and R. M. Metzger, J. Phys. Chem. B 106 (2002) 1215812164.

40. G. J. Ashwell, W. D. Tyrrell, and A. J. Whittam, J. Am. Chem. Soc. 126 (2004) 7102-7110.

41. G. J. Ashwell, W. D. Tyrrell, and A. J. Whittam, J. Mater. Chem. 13 (2003) 2855-2857.

42. G. J. Ashwell, A. Chwialkowska, and L. R. H. High, J. Mater. Chem. 14 (2004) 2848-2851.

43. F. Terenziani, A. Painelli, A. Girlando, and R. M. Metzger, J. Phys. Chem. B 108 (2004)10743-10750.

44. R. M. Metzger, Chem. Rev. 103 (2003) 3802-3834.

45. B. Boldrini, E. Cavalli, A. Painelli, and F. Terenziani, J. Phys. Chem. A 106 (2002) 6286-6294.

46. T. Liu, W.-G. Han, F. Himo, G. M. Ullmann, D. Bashford, A. Toutchkine, K. M. Hahn, and L. Noodleman, J. Phys. Chem. A 108 (2004) 3545-3555.

47. D. Asthagiri, V. Dillet, T. Liu, L. Noodleman, R. L. Van Etten, and D. Bashford, J. Am. Chem. Soc. 124 (2002) 1022510235.

48. T. Bevilaqua, D. C. da Silva, and V. G. Machado, Spectrochim. Acta, Part A 60 (2004) 951-958.

49. R. Wortmann, U. Rösch, M. Redi-Abshiro, and F. Würthner, Angew. Chem., Int. Ed. 42 (2003) 2080-2083.

50. F. Würthner, R. Wortmann, and K. Meerholz, ChemPhysChem 3 (2002) 17-31.
51. F. Würthner, S. Yao, T. Debaerdemaeker, and R. Wortmann, J. Am. Chem. Soc. 124 (2002) 9431-9447.

52. W. Leng, F. Würthner, and A. M. Kelley, J. Phys. Chem. B 108 (2004) 10284-10294.

53. A. M. Kelley, J. Chem. Phys. 119 (2003) 3320-3331.

54. Z. Tian, Y. Chen, W. Yang, J. Yao, L. Zhu, and Z. Shuai, Angew. Chem., Int. Ed. 43 (2004) 4060-4063.

55. O. Ikkala and G. ten Brinke, Science 295 (2002) 24072409.

56. J.-M. Lehn, Science 295 (2002) 2400-2403.

57. F. Würthner, S. Yao, and U. Beginn, Angew. Chem., Int. Ed. 42 (2003) 3247-3250.

58. S. Yao, U. Beginn, T. Gress, M. Lysetska, and F. Würthner, J. Am. Chem. Soc. 126 (2004) 8336-8348.

59. T. S. Balaban, A. D. Bhise, M. Fischer, M. Linke-Schaetzel, C. Roussel, and N. Vanthuyne, Angew. Chem., Int. Ed. 42 (2003) 2140-2144.

60. O. Ohtani, H. Kato, T. Yui, and K. Takagi, J. Am. Chem. Soc. 125 (2003) 14465-14472.

61. S. P. Gromov, E. N. Ushakov, O. A. Fedorova, I. I. Baskin, A. V. Buevich, E. N. Andryukhina, M. V. Alfimov, D. Johnels, U. G. Edlund, J. K. Whitesell, and M. A. Fox, J. Org. Chem. 68 (2003) 6115-6125.

62. J.-W. Lee, J. Mun, C. S. Yoon, K.-S. Lee, and J.-K. Park, Adv. Mater. 14 (2002) 144-147.

63. J.-W. Lee, M. Jung, G. R. Rosania, and Y.-T. Chang, Chem. Commun. (2003) 1852-1853.

64. M. Chudak and B. Juskowiak, Pol. J. Chem. 77 (2003) 303-313.

65. M. J. Hinner, G. Hübener, and P. Fromherz, J. Phys. Chem. B 108 (2004) 2445-2453.

66. G. Hübener, A. Lambacher, and P. Fromherz, J. Phys. Chem. B 107 (2003) 7896-7902.

67. B. Kuhn and P. Fromherz, J. Phys. Chem. B 107 (2003) 7903-7913.

68. I. S. Alaverdian, A. V. Feofanov, S. P. Gromov, A. I. Vedernikov, N. A. Lobova, and M. V. Alfimov, J. Phys. Chem. A 107 (2003) 9542-9546.

69. Q. Zheng, G. S. He, T.-C. Lin, and P. N. Prasad, J. Mater. Chem. 13 (2003) 2499-2504.

70. Y. Iwase, K. Kamada, K. Ohta, and K. Kondo, J. Mater. Chem. 13 (2003) 1575-1581.

71. I. A. Struganova, M. Hazell, J. Gaitor, D. McNally-Carr, and S. Zivanovic, J. Phys. Chem. A 107 (2003) 2650-2656.

72. I. A. Struganova, S. Morgan, and H. Lim, J. Phys. Chem. B 106 (2002) 11047-11050.

73. A. Furube, T. Shiozawa, A. Ishikawa, A. Wada, K. Domen, and C. Hirose, J. Phys. Chem. B 106 (2002) 3065-3072.

74. N. Miyamoto, K. Kuroda, and M. Ogawa, J. Mater. Chem. 14 (2004) 165-170.

75. D. Laage, W. H. Thompson, M. Blanchard-Desce, and J. T. Hynes, J. Phys. Chem. A 107 (2003) 6032-6046.

76. P. Fromherz, ChemPhysChem 3 (2002) 276-284.

77. A. Abbotto, L. Beverina, S. Bradamante, A. Facchetti, C. Klein, G. A. Pagani, M. Redi-Abshiro, and R. Wortmann, Chem.-Eur. J. 9 (2003) 1991-2007.

78. P. Innocenzi, E. Miorin, G. Brusatin, A. Abbotto, L. Beverina, G. A. Pagani, M. Casalboni, F. Sarcinelli, and R. Pizzoferrato, Chem. Mater. 14 (2002) 3758-3766. 
79. B. J. Coe, L. A. Jones, J. A. Harris, B. S. Brunschwig, I. Asselberghs, K. Clays, and A. Persoons, J. Am. Chem. Soc. 125 (2003) 862-863.

80. B. J. Coe, L. A. Jones, J. A. Harris, E. E. Sanderson, B. S. Brunschwig, I. Asselberghs, K. Clays, and A. Persoons, Dalton Trans. (2003) 2335-2341.

81. B. J. Coe, L. A. Jones, J. A. Harris, B. S. Brunschwig, I. Asselberghs, K. Clays, A. Persoons, J. Garin, and J. Orduna, J. Am. Chem. Soc. 126 (2004) 3880-3891.

82. H. Meier, J. Gerold, and D. Jacob, Tetrahedron Lett. 44 (2003) 1915-1918.

83. B. J. Coe, J. L. Harries, J. A. Harris, B. S. Brunschwig, S. J. Coles, M. E. Light, and M. B. Hursthouse, Dalton Trans. (2004) 2935-2942.
84. H. S. Kim, S. M. Lee, K. Ha, C. Jung, Y.-J. Lee, Y. S. Chun, D. Kim, B. K. Rhee, and K. B. Yoon, J. Am. Chem. Soc. 126 (2004) 673-682.

85. I. Kinski, P. Daniels, C. Deroche, B. Marler, and H. Gies, Microporous Mesoporous Mater. 56 (2002) 11-25.

86. N. Miyamoto, K. Kuroda, and M. Ogawa, J. Phys. Chem. B 108 (2004) 4268-4274.

87. G. Klimusheva, A. Koval' chuk, A. Sadovenko, S. Bugaychuk, T. Mirnaya, and A. Ishchenko, Opto-Electron. Rev. 12 (2004) 181-186.

88. I. O. Shklyarevskiy, P. C. M. Christianen, E. Aret, H. Meekes, E. Vlieg, G. Deroover, P. Callant, L. van Meervelt, and J. C. Maan, J. Phys. Chem. B 108 (2004) 16386-16391.

\section{SAŽETAK}

\section{Cijanini koji nose kvaternu azzaromatsku jedinicu}

\section{Wanda Śliwa, Grażyna Matusiak i Barbara Bachowska}

Prikazani su odabrani cijanini s kvaternom azaaromatskom jedinicom, posebno njihovi monomeri, dimeri i polimeri, kao i njihova moguæa primjena. Ukratko su opisani cijanini koji posjeduju NLO (nelinearna optička ) svojstva. 